\title{
The Mediating Role of Perceived Organizational Support in the Effects of Job Stress on Occupational Commitment: Research on Nurses Working in a Foundation University Hospital
} İş Stresinin Mesleki Bağlılık Üzerindeki Etkisinde Algılanan Örgüt Desteğinin Aracılık Rolü: Bir Vakıf Üniversitesi Hastanesinde Çalışan Hemşireler Üzerine Araştırma

(D) Merve KOÇOĞLU SAZKAYA1 ${ }^{1}$, ID Zeynep GÖRMEZOĞLU²

${ }^{1}$ Marmara University, Faculty of Business Administration, İstanbul, Turkey

2Bezmialem Vakıf University, General Secretary, İstanbul, Turkey

\begin{abstract}
Objective: This study aimed to reveal the relationship between the concepts of job stress, perceived organizational support, and occupational commitment on nurses, who are one of the occupational groups most affected by the coronavirus 2019. Only a few academic studies on the relationships between these concepts were carried out in the literature. Therefore, this study aimed to fill the gap mentioned in the literature.

Methods: This study is a quantitative research conducted on 270 nurses working in a foundation university hospital in Istanbul. the data in this study were collected using the questionnaire method, and statistical analyses were performed using SPSS. The participants' demographic characteristics, factor and reliability analyses of job stress, perceived organizational support and occupational commitment variables, mean values of variables, and regression analysis to determine the effects of variables were conducted within the scope of the research.

Results: According to the research results, there are significant relationships between job stress, perceived organizational support, and occupational commitment. Perceived organizational support plays a full-mediating role on the effects of job stress, and occupational commitment is another result of the study.
\end{abstract}

\section{ÖZ}

Amaç: İş stresi, algılanan örgüt desteği ve mesleki bağlılık kavramları arasındaki ilişkiyi ortaya koymak için gerçekleştirilen bu çalışma corona virüs hastalığı-2019 salgınından en çok etkilenen meslek gruplarından biri olan hemşireler üzerine gerçekleştirilmiştir. Yapılan literatür taramasında, bahsi geçen kavramlar arasındaki ilişkilere yönelik akademik çalışmaya pek fazla rastlanılmamıştır. Dolayısıyla, bu araştırmanın orijinalliği literatürde bahsi geçen boşluğu doldurmasıdır.

Yöntemler: $\mathrm{Bu}$ çalışmada, İstanbul'da bir vakıf üniversitesi hastanesinde çalışan 270 hemşire ile nicel bir araştırma gerçekleştirilmiştir. Araştırmada veriler anket yöntemiyle toplanmış olup SPSS ile istatistiksel analizler gerçekleştirilmiştir. Araştırma kapsamında katılımcıların demografik özellikleri, iş stresi, algılanan örgüt desteği ve mesleki bağlılık değişkenlerine ait faktör ve güvenilirlik analizleri, değişkenlere ilişkin ortalama değerler ve değişkenler arası etkiyi belirlemeye yönelik analizler yapılmıştır.

Bulgular: Araştırma sonucuna göre, iş stresi, algılanan örgüt desteği ve mesleki bağlılık arasında anlamlı ilişkiler olduğu belirlenmiştir. İş stresini mesleki bağlılık üzerindeki etkisinde algılanan örgüt desteğinin tam aracı role sahip olması araştırmanın bir diğer sonucudur.
Address for Correspondence: Merve KOÇOĞLU SAZKAYA, Marmara University, Faculty of Business Administration, İstanbul, Turkey

E-mail: merve.kocoglu@marmara.edu.tr ORCID ID: orcid.org/0000-0002-4820-8092
Received: 17.05.2021

Accepted: 17.06.2021

Cite this article as: Koçoğlu Sazkaya M, Görmezoğlu Z. The Role of Perceived Organizational Support in the Relationship between Job Stress and Occupational Commitment: Research on Nurses Working in a Foundation University Hospital. . Bezmialem Science 2021;9(4):465-71. 
Conclusion: In this study, the relationships between the concepts of job stress, perceived organizational support, and occupational commitment are determined. According to the research results, although nurses are exposed to job stress due to working conditions, their occupational commitment increases with the support they receive from their organizations.

Keywords: Job stress, perceived organizational support, occupational commitment, COVID-19
Sonuç: Bu çalı̧̧mada, iş stresi, algılanan örgüt desteği ve mesleki bağlılık kavramları arasındaki ilişki ortaya konmuştur. Araştırma sonucuna göre, hemşireler çalışma koşullarından kaynaklı iş stresine maruz kalmalarına rağmen örgütlerinden almış oldukları destek ile mesleki bağlılıkları artmaktadır.

Anahtar Sözcükler: İş stresi, algılanan örgüt desteği, mesleki bağlılık, COVID-19

\section{Introduction}

Today, ensuring the sustainability of employees who have occupational commitment is an important problem faced by organizations. Occupational commitment is the psychological link between individuals and professions (1). Another definition of occupational commitment is that "it provides a more complete understanding of a person's tie to his/her occupation" (2). According to Meyer et al. (2), occupational commitment has been handled in three dimensions as follows: affective commitment, continuance commitment, and normative commitment. Affective commitment is a person's emotional commitment to their profession $(3,4)$. Meyer et al. (2) expressed affective commitment as "individuals' encountering satisfactory experiences while performing their profession." Continuance commitment is the evaluation of the costs associated with leaving the profession of the individual $(3,4)$. According to Meyer et al. (2), continuance commitment is "the loss or decrease of the value of the investments that individuals have made in their profession until that day when they change their jobs". Normative commitment is the feeling of an obligation to remain in one's profession $(3,4)$. According to Meyer et al. (2), normative commitment is "the attachment of individuals to their profession due to normative pressures."

Occupational commitment may be negatively affected because it develops under or beyond the organizations' control. One of these reasons is job stress (5-8), which is "the individual's awareness or feeling of functional impairment as a result of conditions or events arising from the work environment" (9). Researchers considered job stress in the two following dimensions: time stress and anxiety stress (9-11). Time stress occurs because of crisis management, time pressure at the workplace, too much work to do, but not enough time, and experiences with managers (9). Anxiety stress is when individuals feel emotionally uncomfortable because of the stress they have experienced (9). In other words, anxiety stress is the stress caused by the anxiety and tension arising from the workplace and work conditions (12).

On the other hand, organizations want to change employees' attitudes and behaviors in order to increase their employees' occupational commitment. Organizational support is one of the attitudes that affect employees' commitment to their occupation $(13,14)$. Organizational support means that the organization deals with its employees (15). In other words, it is "employees' perception concerning the extent to which the organization values their contribution and cares about their well-being." (16).
In addition, organizational support also reduces the job stress experienced by employees. Employees who have a perception of organizational support may have a low perception of job stress since they believe that their organizations are by their side even if they experience job stress due to working conditions $(17,18)$.

In recent years, the coronavirus-2019 (COVID-19) pandemic has been a major threat to the whole world and humanity. Almost all sectors were adversely affected, although the health sector comes first among these sectors. In this period, healthcare professionals are serving humanity by struggling to survive, and this situation causes job stress. Despite this, almost all healthcare professionals worldwide are committed to serving humanity and working with great devotion. This shows that the occupational commitment of healthcare professionals is high. In addition, another factor that can affect the occupational commitment of healthcare professionals is the support they receive from the organizations they work for. With the support they receive from their organizations, healthcare professionals feel that their organizations are always with them; thus, their occupational commitment increases, and job stress can be reduced.

This study was conducted on nurses working in a foundation university hospital in Istanbul, and the role of perceived organizational support in the effects of job stress on occupational commitment was discussed. When related literature was examined, studies involving the concepts of job stress, perceived organizational support, and occupational commitment were rarely encountered before, and this has been the source of motivation for this study. In addition, this study has gained originality because it was conducted on nurses, which is one of the groups most affected by the COVID-19 pandemic that affected the whole world and humanity. For this reason, it is thought that this study will contribute to the related literature.

\section{Methods}

\section{Purpose and Importance of the Research}

Recently, the COVID-19 pandemic has been a major threat to the whole world and humanity. Day by day, the working conditions of healthcare professionals are getting more and more difficult, and this situation causes job stress. Despite this, healthcare professionals devote themselves to serve humanity and work with intense labor, effort, and devotion at the cost of their lives. This situation shows that the occupational commitment of healthcare workers is high. In addition, another factor that can 
affect the occupational commitment of healthcare professionals is the support they receive from the organizations they work for. With the support they receive from their organizations, healthcare professionals feel that their organizations are always with them; thus, their occupational commitment increases, and job stress can be reduced. Therefore, this study was carried out to reveal the relationship between the concepts mentioned earlier. Thus, this study aimed to examine the role of perceived organizational support in the effects of job stress on occupational commitment of nurses, who are one of the most important groups of healthcare professionals.

\section{Participants and Sampling of the Research}

This research was conducted on nurses working in a foundation university hospital in İstanbul. According to the information obtained from its human resources department, there were 417 nurses working in the university hospital. The sample size was 201 employees for a population of 417 employees, at a 95\% confidence interval and 5\% significance level. A convenience sampling method was used. The surveys were distributed and collected by the researchers. The research was conducted on a voluntary basis, and the data were obtained from 270 respondents.

\section{Research Model, Variables, and Hypothesis of the Study}

The model developed in line with the purpose of the research is based on the social change theory, which attempts to explain employees' attitudes at work (19). The independent, dependent, and mediating variables of the study were job stress, occupational commitment, and perceived organizational support, respectively.

The model of the research was created to determine the role of perceived organizational support in the effects of job stress on occupational commitment as shown in Figure 1.

For the purpose of this study, the research hypothesis is determined as follows:

$\mathrm{H}_{1}$ : Perceived organizational support mediates the relationship between job stress and occupational commitment.

\section{Measurement Instrument of the Research Variables}

In this research, surveys were used as a means of data collection. The questionnaire used in this research consisted of four main parts. The first part contained questions about the respondents' demographic features.

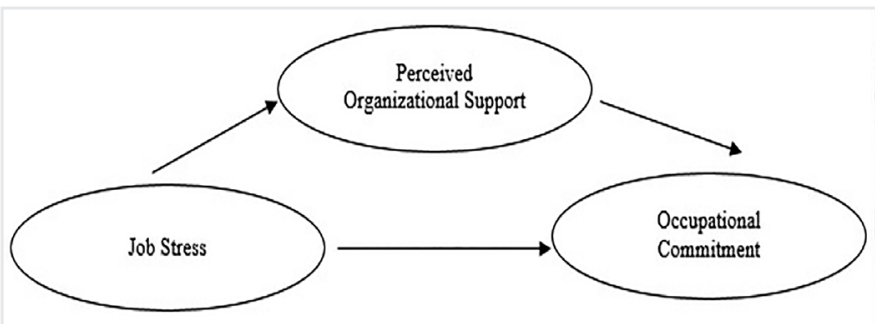

Figure 1. Research model
The second part of the questionnaire form, developed by Parker and Decotiis (9), was a scale with 13 expressions and used to determine the job stress of employees. The job stress scale consisted of the two following dimensions: "anxiety stress" and "time stress". In the literature review, the short form of the scale, consisting of nine statements, was used in this study (20-23). The shortened version was first used by Jamal and Baba (1992) who measured job stress as one construct (10).

The third part of the questionnaire form consisted of statements regarding the perceived organizational support scale. To measure, the shortened version of the scale, which was developed by Eisenberger, Huntington, Hutchison, and Sowa, with eight statements with the highest factor load was used (16). In addition, expressions $2,3,5$, and 7 in the scale were in the reverse direction, and scoring was made in reverse.

The fourth part of the questionnaire comprised expressions about occupational commitment scale, which was developed by Meyer et al. (2). The scale consisted of 18 statements and 3 dimensions. The first six statements measured affective commitment, the next 6 measured continuance commitment, and the last 6 measured normative commitment. Expressions 2, 4, 5, 11, and 14 of the scale are in the reverse direction, and these expressions are scored in reverse.

The questionnaire form was graded using a 5-point Likert scale, except for demographic expressions, ranging from Strongly Disagree (1) to Strongly Agree (5).

\section{Results}

\section{Descriptive Statistics}

The percentages of the respondents' demographic features are as follows: $77 \%$ were women, and $23 \%$ were men. Of the respondents, $35 \%$ were married, and $30 \%$ had children. Their ages ranged from under 25 years (56\%), 26-30 (19\%), 31-35 $(10 \%)$, and 36 and above (15\%). Of the respondents, $88 \%$ were nurses, $6 \%$ were chief nurses, and $6 \%$ were supervisor nurses. Of the respondents, $50 \%$ had a high school degree, $16 \%$ had vocational high school, $30 \%$ had bachelor's degree, and $4 \%$ had a master's degree. Before the COVID-19 pandemic, 83\% stated that they lived with their family, $6 \%$ with their friends, $2 \%$ with others, and $9 \%$ alone. After the COVID-19 pandemic, $82 \%$ of the participants stated that they lived with their family, $6 \%$ with their friends, $2 \%$ with others, and $10 \%$ alone. Meanwhile, most of the participants $(80 \%)$ stated that their daily working hours was $10 \mathrm{~h}$, and $20 \%$ stated that they worked $10 \mathrm{~h}$ or more. Of the participants, $91 \%$ stated that they received their overtime pay, whereas $9 \%$ did not. The participants stated that they had a monthly seizure of $30 \%$ at $1-3$ days, $13 \%$ at $4-6,24 \%$ at $7-9$, and $33 \%$ at 10 or more. The number of years that the participants had been involved in the job experience is $9 \%$ under 1 year, $44 \%$ at $1-5,20 \%$ at $6-10,14 \%$ at $11-15$, and $13 \%$ at 16 or more. The number of years that the participants had been involved in their current hospital ranged from under 1 year (24\%), 1-5 (44\%), 6-10 (24\%), and 11 or longer (8\%). 


\section{Factor and Reliability Analysis of Variables}

In this section, the factor and reliability analyses of the research variables were provided.

\section{Job Stress Factor and Reliability Analysis}

In the factor analysis of job stress scale, the Kaiser-Meyer-Olkin $(\mathrm{KMO})$ value was 0.86 and was significant at 0.000 level. This indicated an excellent value, and data gathered through respondents were suitable for factor analysis (24). By conducting exploratory factor analysis, it was found that job stress scale has created a one dimensional structure. According to the results of the reliability analysis on the job stress scale, the Cronbach alpha was 0.86 , which indicates a high reliability value (26). As a result, after the factor and reliability analyses, the latest job stress scale has one dimension and nine items.

\section{Perceived Organizational Support Factor and Reliability Analysis}

In the factor analysis of perceived organizational support scale, the $\mathrm{KMO}$ value was 0.91 , and this found significant at 0.000 level. This indicates an excellent value, and data gathered through respondents were suitable for factor analysis (24). By conducting an exploratory factor analysis, it was found that perceived organizational support created a one dimensional structure. According to the results of the reliability analysis regarding the perceived organizational support scale, the Cronbach alpha was 0.95 , which indicates a high reliability value (26). As a result, after the factor and reliability analyses, the latest perceived organizational support scale is the same as the original one, consisting of one dimension and eight items.

\section{Occupational Commitment Factor and Reliability Analyses}

In the factor analysis of the occupational commitment scale, the $\mathrm{KMO}$ value was 0.86 . This indicates an excellent value, and data gathered through respondents were suitable for factor analysis (24). According to Hair et al. (25), factors with high cross loadings must be excluded. For this reason, three items are eliminated as follows: "I have put too much into the nursing profession to consider changing now," "I believe people who have been trained in a profession have a responsibility to stay in that profession for a reasonable period of time," and "I am in nursing because of a sense of loyalty to it."

The original occupational commitment scale consisted of three dimensions as follows: affective commitment, continuance commitment," and "normative commitment". By conducting a factor analysis, it is found that occupational commitment scale is measured with three dimensions as in the original scale in this study. The affective commitment, normative commitment, and continuance commitment factor-loading values were 0.89-0.50, $0.82-0.72$, and 0.76-0.62, respectively. Explained variances of the three factors and the total explained variance of the scale are as follows: "affective commitment" as the first factor explains $26 \%$ of the variance, "normative commitment" as the second factor explains $19 \%$ of the variance, and "continuance commitment" as the third factor explains $17 \%$ of the variance. The total explained variance is $62 \%$. According to the result of the reliability analysis on the occupational commitment scale, the Cronbach alpha was 0.88 , which indicates a high reliability value (26). As a result, after the factor and reliability analyses, the latest occupational commitment scale is the same as the original one, consisting of three dimensions.

\section{Descriptive Statistics and Correlation Analysis of Variables}

The correlations between variables, mean, and standard deviations are reported in Table 1.

Table 1 shows that job stress has a significant negative correlation with perceived organizational support $(\mathrm{r}=-0.521, \mathrm{p}<0.01)$, occupational commitment $(\mathrm{r}=-0.130, \mathrm{p}<0.05)$, and affective commitment $(\mathrm{r}=-0.305, \mathrm{p}<0.01)$. Perceived organizational support has a significant positive correlation with occupational commitment $(\mathrm{r}=0.391, \mathrm{p}<0.01)$, affective commitment $(\mathrm{r}=0.433$, $\mathrm{p}<0.01)$, and normative commitment $(\mathrm{r}=0.342, \mathrm{p}<0.01)$. Occupational commitment has a significant positive correlation with affective commitment $(\mathrm{r}=0.727, \mathrm{p}<0.01)$, continuance commitment $(r=0.724, p<0.01)$, and normative commitment $(\mathrm{r}=0.806, \mathrm{p}<0.01)$. Affective commitment has a significant positive correlation with continuance commitment $(\mathrm{r}=0.167$, $\mathrm{p}<0.01)$ and normative commitment $(\mathrm{r}=0.402, \mathrm{p}<0.01)$. Continuance commitment has a significant positive correlation with normative commitment $(\mathrm{r}=0.487, \mathrm{p}<0.01)$

\section{Hypothesis Testing: Measuring Mediating Effect}

This study aimed to demonstrate that there is a mediating effect of perceived organizational support on the relationship between job stress and occupational commitment.

Table 1. Descriptive statistics and correlations for variables

\begin{tabular}{|c|c|c|c|c|c|c|c|c|}
\hline & M & SD & 1 & 2 & 3 & 4 & 5 & 6 \\
\hline Job stress & 2.74 & 1.30 & 1 & $-0.521^{\text {** }}$ & $-0.130^{*}$ & $-0.305^{* *}$ & 0.111 & -0.75 \\
\hline Occupational commitment & 3.36 & 1.04 & & & 1 & $0.727^{\star *}$ & $0.724^{* *}$ & $0.806^{* *}$ \\
\hline Affective commitment & 3.64 & 1.08 & & & & 1 & $0.167^{* *}$ & $0.402^{* *}$ \\
\hline Normative commitment & 3.26 & 1.00 & & & & & & 1 \\
\hline
\end{tabular}


The research hypothesis for this study was determined as follows:

$\mathrm{H}_{1}$ : Perceived organizational support mediates the relationship between job stress and occupational commitment.

To measure the mediating effect, regression analysis was performed in three steps as suggested by Baron and Kenney (27). Table 2 shows that, in the first step of regression, job stress and occupational commitment were added to the model. According to regression analysis findings, there is a significant effect of job stress on occupational commitment ( $\mathrm{p}=0.033$ and $<0.05$ ). In the second step of the hypothesis, job stress and perceived organizational support were added to the model. According to regression analysis findings, there is a significant effect of job stress on perceived organizational support $(\mathrm{p}=0.000$ and $<0.05$ ). In third and last step of hypothesis testing, to determine the mediating role of perceived organizational support on the relationship between job stress and occupational commitment, both steps were examined. The effect of perceived organizational support on occupational commitment is still significant $(\mathrm{p}=0.000$ and $<0.05)$. The result explained that perceived organizational support significantly affects occupational commitment. Also, the effect of job stress on occupational commitment when controlling perceived organizational support is insignificant. It can be stated that there is a fully mediating effect.

Accordingly, it can be concluded that there is a fully mediating effect of perceived organizational support on the relationship between job stress and occupational commitment. Also, it can be stated that if nurses have perceived organizational support, even if they experience job stress, their occupational commitment may increase. Thus, this reveals that $\mathrm{H}_{1}$ is accepted.

\section{Discussion}

This study included a quantitative study of nurses working in a foundation university hospital and aimed to examine the mediating role of perceived organizational support in the effects of job stress on occupational commitment.

According to the results of this study, there is a negative relationship between job stress and occupational commitment. This result is consistent with previous studies in the literature, which were conducted by Barouch Gilbert et al. (5), Jepson and Forrest (6), Klassen and Chiu (7), and Klassen et al. (8). When nurses are exposed to job stress, their occupational commitment may decrease as they cannot work peacefully and happily because of the pressure they have experienced.

Another result of this study is that there is a negative relationship between job stress and perceived organizational support. The studies by Adan-Gök et al. (28), Chen et al. (17), Dawley et al. (18), and Higazee et al. (29) supported this result. Job stress is usually the pressure that occurs on employees because of unfavorable working conditions. Stress caused by negative working conditions is actually an indicator that employees do not receive support from their organizations. In other words, when hospitals support their nurses, their perceptions of job stress may decrease as they will improve their working conditions.

Another result of this study is that there is a positive relationship between occupational commitment and perceived organizational support. This result is also supported with previous studies in the literature, which were conducted by Aydın and Kalemci Tüzün (13), Darolia et al. (14), Kuo et al. (30), and Singh et al. (31). Occupational commitment of employees who receive support from their organizations may increase. In other words, if nurses trust their hospitals and feel that they are by their side under all circumstances, their occupational commitment may increase.

The general result of the study is that perceived organizational support fully mediates the relationship between job stress and occupational commitment. In other words, results of this research claimed that although nurses work under job stress, their occupational commitment will be high when they receive support from their hospitals.

\section{Study Limitations}

The fact that this study was conducted only on nurses working in a foundation university hospital does not mean that the findings will reflect on all nurses. In other words, the results obtained in the research are valid only for the limited universe participating in the research. For this reason, it is impossible to make a generalization about the results of the research beyond this. Another limitation of this study is that it was evaluated using a subjective approach based on nurses' opinions.

Table 2. Regression analysis

\begin{tabular}{|c|c|c|c|c|c|c|}
\hline \multirow{2}{*}{$\begin{array}{l}\text { Regression } \\
\text { model } \\
\text { independent } \\
\text { variable } \\
\text { mediating variable }\end{array}$} & \multicolumn{2}{|c|}{$\begin{array}{l}\text { Model } 1 \\
\text { dependent variable } \\
\text { occupational commitment }\end{array}$} & \multicolumn{2}{|c|}{$\begin{array}{l}\text { Model } 2 \\
\text { dependent variable } \\
\text { perceived organizational } \\
\text { support }\end{array}$} & \multicolumn{2}{|c|}{$\begin{array}{l}\text { Model } 3 \\
\text { dependent variable: } \\
\text { occupational commitment }\end{array}$} \\
\hline & $\beta$ & $p$ & $\beta$ & $\mathrm{P}$ & $\beta$ & $p$ \\
\hline Job stress & -0.130 & 0.033 & -0.521 & 0.000 & 0.101 & 0.126 \\
\hline Perceived organizational support & & & & & 0.443 & 0.000 \\
\hline $\mathrm{R}$ & 0.130 & & 0.521 & & 0.400 & \\
\hline $\mathrm{F}$ & 4.606 & & 99.607 & & 25.476 & \\
\hline $\mathrm{T}$ & -2.146 & & -9.980 & & $\begin{array}{l}1.535 \\
6.751\end{array}$ & \\
\hline R2 & 0.013 & & 0.268 & & 0.154 & \\
\hline
\end{tabular}




\section{Conclusion}

Today, one of the most important problems faced by organizations is to ensure the sustainability of the employment of their employees who are committed to their occupations. Occupational commitment is the psychological link between employees and their profession, and it is the desire of individuals to continue their profession. Occupational commitment decreases because of the unfavorable working conditions that employees often encounter while performing their profession. At the same time, the unfavorable working conditions cause employees to experience job stress, which is a functional disorder that could arise from unfavorable work environment. In other words, employees may lose their commitment to their occupation because of the job stress they have experienced.

Organizations strive to increase the occupational commitment of their employees and use various factors. One of these factors is organizational support, which is the way organizations value and care for their employees. At the same time, organizational support reduces the job stress experienced by employees. In other words, employees who think that their organizations are by their side under all circumstances may have a low perception of job stress if they believe that they receive support from their organization.

Recently, the COVID-19 pandemic has been a major threat to the whole world and humanity. One of the occupational groups that took the first place in combating the epidemic was healthcare professionals. They are serving humanity by risking their own lives. As the pandemic still continues, the working conditions of healthcare professionals are getting harder with each passing day, and this situation causes job stress. Despite this, healthcare professionals worldwide serve humanity by dedicating themselves to their profession. This situation shows that the occupational commitment of healthcare professionals is high. In addition, another factor that may affect the occupational commitment of healthcare professionals is the support they receive from the hospitals they work for. With the support they receive in their hospitals, healthcare professionals feel that their hospitals are always with them and their occupational commitment increases, and job stress can be reduced. Therefore, the general result of this research is that although nurses are exposed to job stress, their occupational commitment will be high when they get support from their hospitals.

In this study, some suggestions were made for organizations and researchers. Organizations should develop policies that will increase the occupational commitment and perceived organizational support of their employees and reduce their job stress. For example, employees should be empowered, and their participation in decisions should be increased. Opportunities such as wage, rewards, and promotions should be done fairly, and equal opportunities to all employees should be provided. In addition, job descriptions of the employees should be reviewed and clearly stated. For example, bureaucratic workloads of nurses should be reduced, and they should be ensured to perform their professions. Moreover, organizations should carry out activities that will increase the motivation of employees. Various social activities should be organized to increase interaction and communication within the organization, such as celebrating employees' birthdays and organizing family picnics to attend together.

In future studies, the concepts of the leadership style, perceived supervisor support, personality, job satisfaction, motivation, organizational commitment, organizational justice, emotional labour, organizational culture and organizational climate should be addressed. In addition, it is thought that considering the distinction between private and public sectors will contribute to the field of social sciences.

\section{Ethics}

Ethics Committee Approval: Bezmialem Vakıf University Rectorate Non-interventional Research Ethics Committee (number: E-54022451-050.05.04-15487/date: 06.05.2021).

Peer-review: Externally peer reviewed.

\section{Authorship Contributions}

Concept: M.K.S., Z.G., Design: M.K.S., Z.G., Data Collection or Processing: Z.G., Analysis or Interpretation: M.K.S., Literature Search: M.K.S., Z.G., Writing: M.K.S., Z.G.

Conflict of Interest: No conflict of interest was declared by the authors.

Financial Disclosure: The authors declared that this study received no financial support.

\section{References}

1. Lee K, Carswell JJ, Allen NJ. A meta-analytic review of occupational commitment: relations with person- and work-related variables. J Appl Psychol 2000;85:799-811.

2. Meyer J, Allen NJ, Smith CA. Commitment to organizations and occupations: Extension and test of a three-component conceptualization. Journal of Applied Psychology 1993;78:538-51.

3. Blau G. On assessing the construct validity of two multidimensional constructs: Occupational commitment and occupational entrenchment. Human Resource Management Review 2001;11:27998.

4. Blau G. Testing for a four-dimensional structure of occupational commitment. Journal of Occupational and Organizational Psychology 2003;76:469-88.

5. Barouch Gilbert R, Adesope OO, Schroeder NL. Efficacy beliefs, job satisfaction, stress and their influence on the occupational commitment of English-medium content teachers in the Dominican Republic. Educational Psychology 2014;34:876-99.

6. Jepson E, Forrest S. Individual contributory factors in teacher stress: the role of achievement striving and occupational commitment. $\mathrm{Br} \mathrm{J}$ Educ Psychol 2006;76:183-97.

7. Klassen RM, Chiu MM. The occupational commitment and intention to quit of practicing and pre-service teachers: Influence of self-efficacy, job stress, and teaching context. Contemporary Educational Psychology 2011;36:114-29. 
8. Klassen R, Wilson E, Siu AF, Hannok W, Wong MW, Wongsri N, et al. Preservice teachers' job stress, self-efficacy, and occupational commitment in four countries. European Journal of Psychology of Education 2013;28:1289-1309.

9. Parker DF, Decotiis TA. Organizational determinants of job stress. Organizational Behavior and Human Performance 1983;32:160-77.

10. Jamal M. Job stress and employee well-being: A cross-cultural empirical study. Stress \& Medicine 1999;15:153-8.

11. Yıldız H, Koçoğlu Sazkaya M. Duygusal emek ile iş stresi ilişkisinin incelenmesi: kamu çalışanlarına yönelik bir araştırma. İstanbul Gelişim Üniversitesi Sosyal Bilimler Dergisi 2021;8:29-50.

12. Arshadi N, Damiri H. The relationship of job stress with turnover intention and job performance: Moderating role of OBSE. ProcediaSocial and Behavioral Sciences 2013;84:706-10.

13. Aydın E, Kalemci Tüzün I. Organizational support sources and job performance relations: what about occupational commitment? Anatolia 2019;30:1-11.

14. Darolia CR, Kumari P, Darolia S. Perceived organizational support, work motivation, and organizational commitment as determinants of job performance. Journal of the Indian Academy of Applied Psychology 2010;36:69-78.

15. Koçoğlu M. Cynicism as a mediator of relations between job stress and work alienation: A study from a developing country-Turkey. Global Business and Management Research 2014;6:24-36.

16. Eisenberger R, Huntington R, Hutchison S, Sowa D. Perceived organizational support. Journal of Applied Psychology 1986;71:5007.

17. Chen Z, Eisenberger R, Johnson KM, Sucharski IL, Aselage J. Perceived organizational support and extra-role performance: which leads to which? J Soc Psychol 2009;149:119-24.

18. Dawley DD, Andrews MC, Bucklew NS. Mentoring, supervisor support, and perceived organizational support: what matters most? Leadership \& Organization Development Journal 2008;29:235-42.

19. DeConinck JB. The effect of organizational justice, perceived organizational support, and perceived supervisor support on marketing employees' level of trust. Journal of Business Research 2010;63:1349-55.

20. Fields DL. Taking the measure of work: a guide to validated scales for organizational research and diagnosis. Thousand Oaks CA: Sage
Publications; 2002.

21. Jamal M, Baba VV. Shiftwork and department-type related to job stress, work attitudes and behavioral intentions: A study of nurses. Journal of Organizational Behavior 1992;13:449-64.

22. Koçoğlu M. Çalışanların örgütlerine yönelik girişimcilik yönelimi algıları, örgüt desteği, kariyer tatminleri ve işten ayrılma niyetleri arasındaki ilişkinin incelenmesi: Otomotiv sektöründe bir araştırma. Akademik Bakış Uluslarası Hakemli Sosyal Bilimler Dergisi 2013;35:1-20.

23. Nair P K. A Path Analysis of relationships among job stress, job satisfaction, motivation to transfer, and transfer of learning: perceptions of occupational safety and health administration outreach trainers (dissertation). Texas A\&M University College Station: 2007.

24. Durmuş B, Yurtkoru ES, Çinko M. Sosyal bilimlerde SPSS’le veri analizi. Istanbul: Beta Yayıncılık; 2011.

25. Hair Jr F. Joseph, Anderson, E. Rolph, Tatham, L. Ronald, and Black, C. William. multivariate data analysis. Upper Saddle River, NJ: Prentice Hall Inc.; 1998.

26. Sekaran U. Research method for business: A skill building approach. USA: John Wiley \& Sons; 1992.

27. Baron RM, Kenney DA. The moderator-mediator variable distinction in social psychological research: Conceptual, strategic, and statistical considerations. Journal of Personality and Social Psychology 1986;51:1173-82.

28. Adan-Gök Ö, Akgündüz Y, Alkan C. The effects of job stress and perceived organizational support on turnover intentions of hotel employees. Journal of Tourismology 2017;3:23-32.

29. Higazee MZA, Rayan A, Khalil M. Relationship between job stressors and organizational support among Jordanian nurses. American Journal of Nursing Research 2016;4:51-5.

30. Kuo MHC, Chang Y, Chang WC. Perceived organizational support as a mediator of managerial coaching skills and occupational commitment. Public Administration Research 2014;3:17-32.

31. Singh R, Zhang Y, Wan M, Fouad NA. Why do women engineers leave the engineering profession? The roles of work-family conflict, occupational commitment, and perceived organizational support. Human Resource Management 2018;57:901-14. 